2. Бех І. Д. Особистісно орієнтоване виховання : [наук.-метод. посібн.] / І. Д. Бех. - К : ІЗМН, 1998. - 204 с. З. Білоусова В. О. Теорія і методика гуманізації відносин старшокласників у позаурочній діяльності загальноосвітньої школи : [монографія] / В. О. Білоусова. - К. : ІЗМН, 1997. - 326 с. 4. Мясищев В. Н. Социальная психология и психология отношений: Проблемы общественной психологии / В.Н.Мясищев. - К : ІЗМН,1997. - 320 с. 5. Педагогічна майстерність : [підручник] / [Зязюн I. А., Крамущенко Л. В., Кривонос І. Ф. та ін.]; за ред. І. А. Зязюна. - [2-ге вид., допов. і переробл.]. - К. : Вища школа, 2004. - 422 с. 6. Проблемы гуманизации: Новое осмысление старых проблем : тезаурус / науч. ред. Ю. Н. Кулюткин. - СПб : Логос, 1997. - 210 с. 7. Сущенко А. В. Гуманізація педагогічної діяльності вчителя як предмет наукового осмислення // Педагогіка і психологія формування творчої особистості: проблеми і пошуки : [зб. наук. праць] / ред. Т. І. Сущенко та ін. - Київ - Запоріжжя. - 2003. - Вип. 28. С. 41 - 49. 8. Якунин В. А. Педагогическая психология : [учеб. пособ.] / В. А. Якунин. - СПб. : Изд-во Михайлова В. А., 2000. $349 \mathrm{c}$.

УДК 371.134:33

О. А. Маліцька, аспірант,

Міжрегіональна академія управління персоналом, Інститут імені П. Калнишевського

\title{
ПЕДАГОГІЧНИЙ МЕНЕДЖМЕНТ ЯК КОНЦЕПЦІЯ РОЗВИТКУ ОСВІТНІХ ЗАКЛАДІВ
}

У статті проаналізовано основні аспекти модернізації освітніх закладів, які пов'язані з інтеграцією національних освітніх закладів до єдиного європейського освітнього простору. Автор систематизує основні завдання педагогічного менеджменту, визначає рівні в діяльності менеджера сфери освіти.

Ключові слова: педагогічний менеджмент, педагогічна продукиія, умови ефективного управління, критерії ефективності.

В статье проанализированы основные аспекты модернизачии учебных учреждений, связанные с интеграцией национальных образовательных систем в единое европейское образовательное пространство. Автором систематизированы основные задания педагогического менеджмента, определены уровни в деятельности менеджера сферы образования.

Ключевые слова: педагогический менеджмент, педагогическая продукция, условия эффективного управления, критерии эффективности.

The modern aspects of educational institutions' modernization related to integration of national educational institutions into the unified European educa- 
tional field were analyzed. The author systematized the main goals of pedagogical management and determined the functioning levels of management in educational field.

Key words: pedagogical management, pedagogical production, conditions of effective management, effectiveness criteria.

Сучасний заклад освіти будь-якої форми власності як елемент соціокультурної сфери виробництва особистості вже $є$ не цілком державним, а державно-суспільним, і реально функціонує в умовах нецентралізованої планової системи народного господарства, зокрема в просторі суспільства перехідної до ринку економіки. А це, у свою чергу, передбачає необхідність заміни концепції традиційного адміністративнокомандного управління ним на адекватну сутності й закономірностям розвитку ринкових відносин концепцію педагогічного менеджменту. Остання концепція спрямована на забезпечення високої ефективності та прибутковості функціонування сучасного закладу освіти як специфічної педагогічної системи з урахуванням витрат внутрішніх $\mathrm{i}$ зовнішніх ресурсів, а також впливів кардинально зміненого зовнішнього середовища - ринку освітніх послуг і ринкових відносин сучасного суспільства. Також суттєвий вплив на реформування в цій галузі відбувається за рахунок інтеграції України до європейського освітнього простору, що об'єднує освітні системи різного типу та рівня за умови збереження їх самобутності. Процес створення європейського простору вищої освіти (Болонський процес) було започатковано у 1999 році та висуває низку вимог, які повинні здійснити країни учасниці, що і зумовлює реформування системи надання освітніх послуг та структури управління освітнім закладом.

На зміну традиційному «управлінню» має прийти «педагогічний менеджмент», якщо об'єкт управління набуває якостей суб'єкта ринкових, комерційних, соціально-економічних відносин, а конкурентна боротьба серед національних освітніх систем та загальне реформування навчальних закладів вимагає нової системи управління як освітнім процесом, так і установою, що надає освітні послуги.

Mema cmammi - проаналізувати інноваційні підходи до управління навчальними закладами та 3'ясувати необхідність упровадження педагогічного менеджменту в установах, які надають освітні послуги.

Поняття «менеджмент»у психолого-педагогічній літературі вживається в різних словосполученнях, основними 3 
яких $\epsilon$ такі: «шкільний менеджмент» (М. Латипова, А. Ньомов, Т. Шамова), «менеджмент в освіті» (Н. Коломийський, В. Крижко, С. Павлютенков), «освітній та навчальний менеджмент» (Д. Дзвінчук, В. Козаков), «педагогічний менеджмент» (В. Бондар, К. Вазіна, Г. Закорченна, В. Маслов, В. Симонов, В. Шаркунова) [2].

Аналіз системи управління різними типами сучасних навчальних закладів України в дослідженнях В. Бондаря, Л. Кащук, Н. Коломийського, Н. Комаренко, В. Крижка, О. Мармизи, В. Маслова, Є. Павлютенкова, Н. Шапошнікової, В. Шаркунової та інших дозволяє сформулювати принципи педагогічного менеджменту, які забезпечать високу якість управління педагогічними колективами та педагогічними системами загалом.

Сучасна система освіти у своїй конкурентній боротьбі між навчальними закладами країни та транснаціональною освітою, яку надають заклади європейського освітнього простору, вимагає визначення нових вимог до суб'єктів надання освітніх послуг. До таких висновків спонукає й аналіз досвіду запровадження Болонської системи в європейських країнах та Україні. Прихильники Болонської міжурядової реформи роблять акцент на доцільності створення Європейського простору вищої освіти. Зміст Болонського процесу передбачає єдині умови визнання дипломів про освіту, уніфіковану систему вчених ступенів, термінів навчання, оцінювання знань та форм навчання. Болонський процесс спирається на гармонізацію освітніх систем в Європі, а його основними спонукальними чинниками $є$ посилення конкуренції з американськими університетами, потреба оптимізації працевлаштування дипломованих фахівців у країнах $\mathrm{CC}$ $[5$, c. 8]. Тому надзвичайно важливими принципами є мобільність студентів і викладачів, відкритість європейської вищої освіти світові. А це, у свою чергу, зумовлює використання в педагогічній діяльності нових парадигм управління 3 використанням світових напрацювань у цій галузі.

Отже, уведення терміна «менеджмент» у теорію вітчизняної педагогічної науки і практики зумовлено такими чинниками:

- по-перше, універсальність наукових підходів і технологій, розроблених у межах теорії сучасного менеджменту, дає можливість застосувати їх у різних сферах управління, 
зокрема й у сфері керування педагогічними системами, а також у різних національних середовищах;

- по-друге, понятійна ідентифікація термінів «менеджмент» та «управління» дає змогу інтегрувати світовий досвід у теорію менеджменту освіти в Україні.

Термін «педагогічний менеджмент» $є$ найбільш вживаним у вітчизняній літературі та розглядається з таких позицій [2]:

- педагогічний менеджмент виявляє свою сутність як наука про управління педагогічними системами, завданням якої $\epsilon$ пошук і розробка засобів та методів, що сприяють найефективнішому досягненню цілей сучасних закладів освіти, підвищенню продуктивності праці їх співробітників, досягненню рентабельності та прибутковості педагогічного «виробництва», виходячи 3 конкретних умов внутрішнього та зовнішнього середовища, зумовленого розвитком ринкової економіки;

- педагогічний менеджмент виявляє свою сутність як певна організація роботи керівних працівників, допоміжного персоналу та педагогічного колективу закладу освіти для досягнення поставленої мети найбільш раціональними способами;

- педагогічний менеджмент розуміють як організацію діяльності закладу освіти, що має певний склад і структуру, у межах яких реалізуються свідомо заплановані та скоординовані заходи, спрямовані на досягнення загальних освітньовиховних цілей;

- терміном «педагогічний менеджмент» фіксується система управління, де певний заклад освіти чи його окремий підрозділ $є$ керованим об'єктом саме в умовах ринкової економіки, що мають зовнішне середовище, - ринкові відносини, до реального стану яких цей заклад має пристосовуватися шляхом зворотного зв'язку. Результатом зворотного зв'язку закладу освіти з ринком освітніх послуг та іншими елементами зовнішнього середовища є управлінське рішення, що передбачає перетворення інформаційних, технологічних, матеріальних, фінансових, трудових та інтелектуальних ресурсів для досягнення кінцевих результатів закладу освіти - забезпечення високого рівня научуваності й вихованості учнів, а також прибутковості господарської діяльності. Цього досягають шляхом мінімізації витрат на сировину, матеріали, енергію, фінансування, оплату праці та максимізації прибутку від результатів педагогічного виробництва - якості зага- 
льноосвітньої підготовки випускників закладу освіти як педагогічної «продукції» та надання додаткових освітніх послуг тощо;

- «педагогічний менеджмент» розуміють як особливий тип умілості та адміністративні навички, що пов’язують із діяльністю певної особи, - менеджера освіти як професійного управлінця. У такому контексті педагогічний менеджмент виявляється через набір певних поведінкових правил, притаманних статусу керівника закладу освіти особливого типу, який виконує сукупність міжособистісних, інформаційних та організаційно-технологічних ролей в умовах відсутності повного стандарту і переліку управлінських завдань; використовує особистісні якості як основне джерело й засіб управління; діє в нестандартних ситуаціях; постійно змінює організаційні ситуації; визначає загальний напрям руху керованої педагогічної системи, іiі змін і особливостей подальшого розвитку.

Отже, на основі проведеного порівняльного аналізу термінів, можна зробити висновок, що «педагогічний менеджмент», на відміну від «внутрішньо шкільного управління» включає в себе економічний, соціально-психологічний та структурно-функціональний механізм, який спрямовується на розв'язання проблем взаємодії учасників навчальновиховного процесу закладу освіти в реалізації його завдань, що виникають в процесі господарської діяльності зумовленої дією ринкових відносин. Навчальний заклад розглядається як діючий елемент загальної ринкової економіки країни, який здійснює свою діяльність у галузі освітніх послуг, ураховуючи нові показники та критерії якості наданих послуг та показники прибутковості або рентабельності як суб'єкта господарської діяльності.

Особливістю педагогічного менеджменту $є$ те, що він включає в себе економічний аспект, який утворюють три блоки, - внутрішньоорганізаційне управління, управління педагогічним виробництвом (Г. Щедровицький) і управління педагогічним персоналом, об'єктивно зумовлене здійсненням господарської діяльності закладу освіти саме в ринкових умовах, коли результати управлінської та господарської діяльності учасників навчально-виховного процесу отримують кінцеву оцінку на ринку освітніх послуг у процесі збуту «педагогічної продукції» (А. Макаренко).

Структурно-функціональними компонентами педагогічного менеджменту є: мета діяльності (запланований, очікуваний 
результат); суб'єкт діяльності (директор, його заступники, учителі, учні); об'єкт діяльності (другий суб'єкт) - виконавець розпоряджень менеджера освіти (учень, учитель, заступники директора); зміст діяльності (навчально-пізнавальна, управлінська та інша інформація); способи діяльності (методи і стиль взаємодії вчителя з учнями, керівника 3 учителями й учнями).

Слід зауважити, що предметом праці менеджера освіти $є$ діяльність керованого ним суб'єкта, продуктом праці - інформація, знаряддям праці - слово, мова, мовлення. Результат праці менеджера освіти - ступінь навченості, вихованості й розвитку об'єкта (другого суб'єкта) педагогічного менеджменту - учнів.

Нині відбувається перехід від державного до державносуспільного типу управління освітою в Україні. I передувати цьому повинні демократизація та децентралізація системи управління освітою. Особливістю управління сучасною українською системою освіти є необхідність забезпечення керівними кадрами (лінійними і функціональними менеджерами освіти) не тільки оптимальної діяльності, а й випереджального розвитку певної організації чи окремого навчальновиховного закладу в умовах демократизації суспільства, переходу до нового рівня функціонування педагогічних макрота мікросистем у цілому. Досягти цього можна тільки шляхом упровадження в національну систему освіти сучасних технологій управління, відповідного науково-методичного забезпечення, створення нового - ринкового господарського механізму, відновлення цільових, операційно-технологічних i соціально-психологічних функцій керування та інших факторів [2].

Вихідними положеннями традиційної вітчизняної концепції управління освітою сьогодні $€$ застарілі визначення управління як особливого виду діяльності керівного й адміністративного характеру, що здійснюється в межах постійно діючої цілеспрямованої системи колективної праці.

Ця концепція стримує розвиток відповідних інноваційних процесів як у сфері загальноосвітньої та професійної підготовки нового покоління, так і в системі управління ними на засадах педагогічного менеджменту.

Найбільш важливі позиції нової парадигми управління українською перехідною економікою, зокрема національною системою освіти, зводяться до такого: відмова від управлін- 
ського раціоналізму класичних шкіл менеджменту; використання в практиці управління досягнень теорії систем, що полегшує завдання розгляду організації в єдності ії складових, нерозривно пов'язаних із зовнішнім світом; використання в процесі управління засобів ситуаційного підходу; визнання соціальної відповідальності менеджменту як перед суспільством загалом, так і перед колом людей, які працюють у системі освіти; орієнтація на нові умови і фактори розвитку суспільства; втілення нових принципів управління; гнучке поєднання методів ринкового регулювання 3 державним регулюванням соціально-економічних процесів; формування та функціонування ринкових суб'єктів господарювання як відкритих і соціально орієнтованих систем; самоврядування на всіх рівнях і перехід до поліцентричної системи господарювання; поєднання ринкових й адміністративних методів управління підприємствами, організаціями й закладами державного сектора економіки [3].

Отже, основною метою педагогічного менеджменту у сфері професійної освіти є забезпечення максимальної ефективності процесу професійної освіти людини через єдність управління заданим процесом, а також керівництва педагогами й учнями, студентами, слухачами.

Завдання педагогічного менеджменту визначаються змістом управління. У свою чергу, зміст управління - це сукупність функцій управління, до яких належать: 1) планування; 2) організація; 3) регулювання; 4) контроль; 5) облік; 6) аналіз.

До основних завдань педагогічного менеджменту можна віднести:

- у галузі прийняття та реалізації рішень: планування діяльності підлеглих на різних щаблях ієрархії закладу освіти та перебігу навчально-виховного процесу - розробка стратегії діяльності; оформлення управлінських рішень: складання відповідних планів і програм з чітким визначенням змісту роботи, термінів виконання, відповідальних тощо; підготовка та прийняття управлінських рішень, інструктаж підлеглих, підбір кадрів та розподіл обов'язків відповідно до їх психологічних особливостей; проведення інструктажів у ході виконання рішень та проведення зборів, нарад тощо; здійснення поточного й підсумкового контролю та обліку виконання управлінських рішень; аналіз роботи учня (студента), акаде- 
мічної групи, педагогів, закладу освіти згідно з ієрархією системи освіти;

- у галузі створення умов, необхідних для виконання рішень: створення сприятливого морально-психологічного клімату в педагогічному та учнівському (студентському) колективах, що сприятиме ефективному досягненню мети освіти; здійснення педагогічного та ділового спілкування в ході реалізації управлінського рішення;

- у галузі підвищення ефективності управління: розробка перспективних напрямків та вибір способів самовдосконалення, управління педагогами, учнями (студентами), навчально-виховним процесом i, відповідно, постановка нових цілей і завдань; формування індивідуального стилю діяльності менеджера, що оптимально враховуватиме всі особливості педагогічного i/або учнівського (студентського) колективу, яким він керує [2].

Успіх у досягненні основної мети і виконанні завдань педагогічного менеджменту залежить від низки умов, які можна поділити на чотири групи:

1. Особистісний фактор керівника (рівень його підготовленості й професіоналізму, його цільові настанови, ціннісні орієнтації та потреби).

2. Морально-психологічний клімат у системі суб'єктсуб'єктних відносин (стиль відносин та рівень зацікавленості у спілкуванні).

3. Часові характеристики та умови його діяльності.

4. Просторові характеристики та умови його діяльності (матеріально-технічне забезпечення, гігієнічні й естетичні умови).

Реалізація принципів педагогічного менеджменту практично здійснюється шляхом застосування різноманітних методів управління, які завжди мають бути адекватні поставленим цілям і завданням педагогічного менеджменту. У свою чергу, усі методи педагогічного менеджменту умовно можна розподілити на такі групи: методи психолого-педагогічного впливу; адміністративні методи; економічні методи; методи громадського впливу.

Основними критеріями ефективності професійної праці менеджера сфери освіти є: оптимальність, раціональність, конкретність мети, перспективність, актуальність, активність і самостійність. 
Рівні в діяльності менеджера сфери освіти: репродуктивний - на ньому керівник обмежується збором інформації про роботу педагогів та повідомленням педагогічному колективу цієї інформації, а також того, що він знає з окремих питань методики професійного навчання та виховання; адаптивний керівник здатний визначати суттєві моменти в роботі педагогів, концентрувати на них увагу педколективу, трансформувати отриману інформацію про роботу колективу в індивідуальні професійні особливості кожного педагога; локальномоделювальний - керівник здатний моделювати не тільки окремі аспекти педагогічної діяльності, а й працювати 3 педагогами з окремих питань навчально-виховного процесу; системно-моделювальний - керівник здатний моделювати системний розвиток навчально-виховного процесу з урахуванням актуальних проблем освіти; екстраполяційний - керівник здатний створювати модель перспективного, випереджального розвитку навчального закладу на основі вивчення тенденцій соціального прогресу.

Найбільшу ефективність процесу управління закладом освіти можна забезпечити за умови досягнення менеджером системно-моделювального й особливо екстраполяційного рівня управлінської діяльності.

\section{Лiтература}

1. Вульфсон Б. Л. Мировое образовательное пространство на рубеже XX-XXI вв. / Б. Л. Вульфсон // Педагогика. - 2002. № 10. - С. 3-8. 2. Педагогіка вищої школи : [навч. посібн.] / 3. Н. Курлянд, Р. І. Хмелюк, А. В. Семенова та ін.; за ред. 3. Н. Курлянд. - [2-ге вид., перероб. і доп.]. - К. : Знання, 2005. С. 260-305. 3. Слєпкань 3. І. Наукові засади педагогічного процесу у вищій школі : [навч. посібн.] / 3. І. Слєпкань. - К. : Вища школа, 2005.-194 с. 4. Устемиров К. Профессиональная педагогика / К. Устемиров, Н. Р. Шаметов, И. Б. Васильев; [под ред. К. Устемирова]. - Алматы, 2005. - С. 194-265. 5. Шевченко Л. С. Транснаціональна освіта в контексті економічної безпеки України. / Л. С. Шевченко // Вісник НЮА ім. Я. Мудрого. - 2011. -№ 4. C. 5-17. 